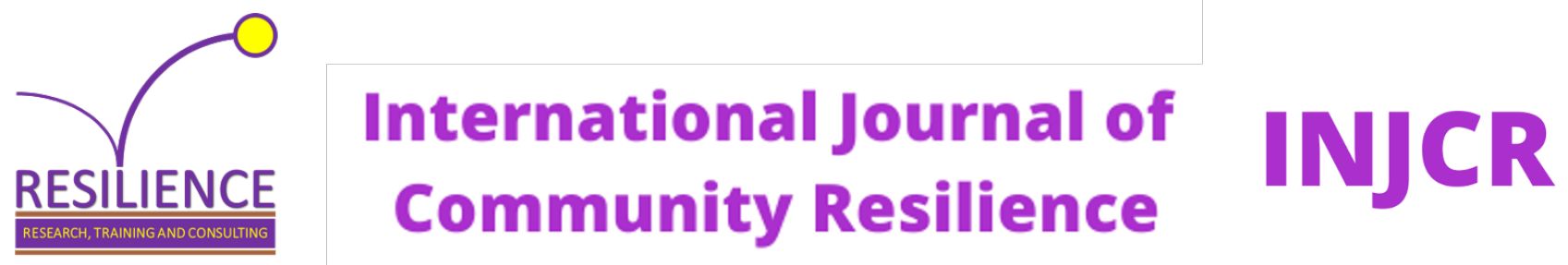

Case Study

ISSN: 2773-7195

๑) (क) (1)

\title{
Community Work Approach in Addressing Social Problems: Three Community Case Studies from Sri Lanka
}

\author{
Ven. Omalpe Somananda $1^{*}$ \\ ${ }^{1}$ Buddhist and Pali University of Sri Lanka. Visiting Researcher, Asian Research Institute for International \\ Social Work (ARIISW). Shukuthoku University - Japan.
}

* Correspondence: omalpes@bpu.ac.lk

Submitted $\quad: 28.04 .2021$

https://doi.org/10.51595/11111161

Human development is at the center of social work to intervene in diverse problems affecting humanity. Community work is a direct method of community development that attempts to serve many people at a macro level. A community case study documents a local experience about delivering services to meet an identified need. This paper aims to illustrate three examples of community case studies that were developed while working with three diverse communities in Sri Lanka. The first community case study describes efforts to efforts to promote social harmony through child engagement in a rural community with ethnoreligious diversity in the Polonnaruwa District. The second community case study documents prioritizing several problems faced by an urban, underserved community located close to the Kolonnawa Garbage dump in the Colombo District. The third case study is on women's engagement in community development and harmony in a peri-urban community in the Gampaha District. The paper provides evidence for the effectiveness of community work in addressing diverse social issues in communities.

Key words: Community case study, Community work, social harmony, macro-level practice 


\section{Introduction}

Paul Spicker defined a community as "a group of people linked by common characteristics or culture; a group of people linked through social relationships, people living in a confined geographical area; people who share a set of common interests" (Brager \& Specht, 1973). A community can be defined as a social unit of any size that shares common values in simple language.

Social work is a profession that helps people solve their problems by themselves (Canadian Association of Social Workers, 2011). The major role of professional social work is human development. Social work will intervene in various perspectives to solve human problems. Basic approaches and methods have been identified in social work as follows (Chukwu, 2019):

1. Social casework for individuals and family

2. Social group work for social groups, and

3. Community work for community development.

The community work method can be described as the most popular and the main method of community development in various countries of the world. The specialty of this is that it can serve a large number of people simultaneously at a macro level. Community work is one of the methods in social work that approaches the service user directly in practice; hence it is one of the direct methods in social work (Department of Social Work, 2017).

When examining the history of social work, it is clear that the community organization method is also referred to as community work (Ife, 1995). Community work has been prescribed in the Social Work discipline in Sri Lanka (Sri Lanka School of Social Work, National Institute of Social Development, Sri Lanka, 2016).

Community work is not a process that ends when the Community worker leaves the community or finishes one activity. Community development only can be achieved through a successful community work process that involves identifying needs, prioritizing them, finding available resources, planning activities to fulfill the needs, implementation, and monitoring and evaluation. The ultimate goal of community development can be achieved through such continuous processes and empowering the community (Ife, 1995).

Community organization is another term that is often used in working with communities. It includes a variety of efforts by religious institutions, community-based organizations, hospitals, government and nongovernment welfare agencies, schools, city planning agencies, and other organizations to improve the community. Community work and community organization are terms often used interchangeably (Brager \& Specht, 1973).

The importance of community work as a part of professional practice has been well highlighted for teachers, social workers, the clergy, health workers, architects, planners, administrators, and others (Bureau of Labor Statistics, U.S. Department of Labor, 2021). Social work was initially referred to as "community work." Later, with the advancement of the social work profession, community work has been used to refer to a community organization.

A community case study documents a local experience about delivering services to meet an identified need (Dredge \& Hales, 2012). Community-based studies often rely on community engagement principles, which are not typically incorporated in the more traditional science-based approach to evidence-based program development. Community case studies are used in all areas of social development such as agriculture, education, health, and infrastructure development, working with diverse audiences including children, youth, women, old age, persons with disabilities, and marginalized groups. Community case studies can be used as powerful tools in sharing the learning with the community itself as a part of their developmental process.

This paper aims to illustrate three examples of community case studies developed while the author and his team worked with three diverse communities in Sri Lanka.

\section{Methods}

Three community case studies are presented as examples to demonstrate the usefulness of an experiential learning methodology. (Figure 1). 


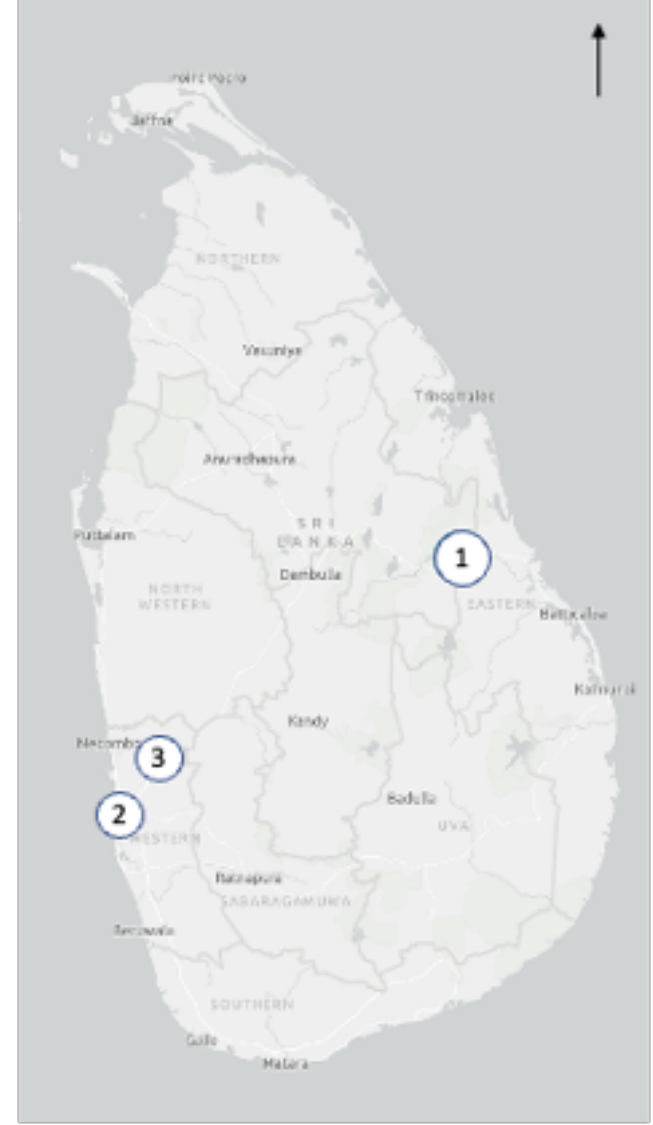

1. Community Case Study 1 Promoting Social Harmony through Child Engagement

2. Community Case Study 2 Prioritizing Community Problems

3 Community Case Study 3 Women for Community Development and Harmony

Figure 1: Map of Community Case Study Sites

Each community case study is based on the fieldwork performed in three different communities in Sri Lanka through social workers in Sri Lanka. During all three community case studies, the community's social, cultural, geographical, economic, and physical information was gathered through observation, interviews, and group discussions. Need assessments were carried out using a mixture of quantitative and qualitative methods, including observations, community surveys, Key Informant Interviews, Focus Group Discussions, and Community Meetings. Specific interventions used in each community case study are elaborated on later.

International Journal of Community Resilience

\section{Results}

Three community case studies are presented to showcase three different examples of the community work approach by social workers. The first community case study describes efforts to promote social harmony through child engagement in a rural community $\mathrm{n}$ with ethnoreligious diversity in the Polonnaruwa District. The second community case study documents prioritizing several problems faced by an urban, underserved community located close to the Kolonnawa Garbage dump in the Colombo District. The third case study focuses on women's engagement in community development and promoting harmony in a peri-urban community in the Gampaha District.

\subsection{Community Case Study 1: Promoting Social Harmony through Child Engagement}

Background: The community for this case study is located in the Welikanda Divisional Secretariat area in the Polonnaruwa District. It was identified as māyimgammāna (a border village between the government and terrorist-controlled areas of Sri Lanka) during the internal conflict in Sri Lanka.

Justification: The concept of social harmony in that area was a necessary and vital factor. A divided and segmented environment had been created due to the misunderstanding and mistrust between the different ethnic communities caught in the midst of the conflict. Focusing on children to build peaceful and harmonious relations between the different ethnic groups proved a logical step.

Objective: The main aim of this program was to build social harmony via the development of social relationships.

Methods: The case study documents community mobilization experience from 2001 to 2004 in this area. Children's societies were formed $\mathrm{n}$ the Mahindagama GND, including in the five villages as Nagasthenna, Kurulubedda, Mahindagama, Kadawathmaduwa, Aselapura, Pūnanni, and Ransarateannena. The Pūnanni Children's society consisted of Muslim children and their held 27 members. The children's society of Ransarathenna (a predominantly Tamil Village) consisted of 36 members. Sinhalese predominantly inhabited the other five villages and 
consisted of 48, 37, 58, 18, and 40 children. Accordingly, the numbers of Sinhala, Muslim and Tamil children in these societies totaled 264.

The activities conducted under this project involved the creation of the following social organizations:

- Seven libraries for children

- Seven children's societies

- Seven early child development centers

- Seven parent societies

While organizing these activities, the following approaches were used for the promotion of social harmony:

- $\quad$ Sporting events

- Discussions

- Seminars

- Religious festivals

- Folk games

- Exchange programs

- Awareness programs

- Income-generation programs

- Recreational tours

- Educational programs.

Results: The activities helped to the development of peaceful and harmonious relations amongst children belonging to different ethnic communities. In addition, the project also contributed to the development of religious harmony, reduction of mistrust between the members of different ethnic communities, and the promotion of respect towards religious beliefs, rituals, and practices.

Reflections: While working with children from different ethnic and religious groups, the following ideas promoting social harmony were identified:
- "All ethnic and religious groups must live in harmony."

- "Every individual has the right to believe, practice and live by his or her religion or faith of choice."

- "People should stand against unethical religious conversions by coercion or by force."

- "All forms of public messaging, written or audiovisual which creates anger, hatred and revives bad memories of the past should be stopped."

- "We should learn from the past mistakes and prevent them in the future."

- "Creation and admiration of heroic memorials should be stopped."

- "Present and future generations are not responsible for what happened in the mistakes that have happened in the past."

- "All individuals and groups who are trying to create ethnic and religious violence should be banned from doing so."

- "We should uphold the unity of mankind among people of all faiths."

It was found that the education system should contribute towards peacebuilding, promotion of civic values, and social cohesion. The government should be encouraged to promote peace and social harmony through education. The development of progressive curriculums and textbooks should be used in schools to promote understanding, harmony, and friendship among human beings despite the diversities in faith, religion, belief, culture, and language is recommended. In addition, it is important to address the cultural, social, economic, political, and religious diversities, not as a source of division, but as a source of harmony, tolerance, peace, and friendly relations among nations as well as racial and religious groups. Education at all levels is one principal means to build a culture of peace. Civic and citizen education must be offered to students as a compulsory subject in the GCE O/L Examination. Another key necessity is to promote bilingual and trilingual education starting from lower secondary classes so that the children from different ethnic groups can study together. With regards to the teaching and learning methodologies, engaging methods such as seminars and workshops should be 
organized by school teachers to teach civics and citizenship education and history through practical sessions than exam-oriented concepts and theories. Teacher development programs should be introduced to equip the teachers in accepting the real nature of Sri Lankan society and to promote respect for diversity and equality.

\subsection{Community Case Study 2: Prioritising Community Problems}

Background: The Dhahampura village is an underserved urban community surrounded by similar settlements and the largest unplanned garbage dump that serves the municipality of Colombo city, the capital of Sri Lanka. It is located in 511/A Dahampura Grama Niladhari Division (GND) in Kollonnawa Divisional Secretariat (DS). Dahampura GND spreads nearly 640 acres, and it is margined by Wellampitiya Vidhyawardhane School, Nagahamulla, ColomboAwissawella road, and Kolonnawa town. The villages within this GND are Jahena, the section of Wellampitiya, and Dahampura. This community came into existence by illegal and unplanned settlements in $1980-1990$.

A linear human settlement pattern could be seen in this village, with a total population of 1210 from 309 housing units who belonged to 309 house units. All houses were single floored. None of the houses have title deeds, and all lands of the houses are categorized as unauthorized. Three lanes characterize the village: One lane is allocated for houses of government workers, and the other two are allocated for laborers and non-government workers. The female population was higher than the male population in this village. The community members represented all age categories: infants, children, young people, middleagers, and senior citizens.

Ethnic and religious diversity could be seen within the community. The majority of the community members are Sinhalese, along with many Muslims. There are considerable numbers of Tamis with very few Burghers. Most of the Sinhalese people are Buddhists. Muslims believe in Islam, and Tamils believe in Hinduism. Most of the Tamil and Muslim people can speak in Sinhala. In the meantime, most of the Sinhalese people can speak in Tamil.

International Journal of Community Resilience
Most marriages occur among young men and women within the same community. It does not matter for either partner to be from a different ethnic or religious background in this community. Additionally, all community members celebrate all cultural and religious events together. They helped each other in cash and inkind in organizing such celebrations. Getting together to help others, especially during hard times, was a part of the community culture. The mixed cultural background can be seen clearly in this community. On the other hand, the same situation has contributed to social disorganization since the formal cultural norms and structures were not so strong. The unity was apparent within the community during festive occasions and at times of crisis. Nevertheless, there was much isolation of families and individuals mostly due to their economic struggles.

Community members belonged to lower to middle economic classes. Most community members were underemployed. Poverty was quite prevalent in the community. Almost every adult was in a struggle of winning their daily bread. Community members were engaged in the industrial sector as laborers in the government or private sector or daily-waged workers. Some of them have started small-scale home-based selfindustry in this community. Agriculture was not practiced in this community due to the lack of resources. Only two individuals were engaged in the service sector. There was only one small shop inside the community.

The garbage dump was a necessary evil to the community. Collecting recyclable items from the garbage dump and re-selling was an additional income generation for most community members. It is the norm for the youth and the children to support the adults in the scavenger hunt rather than going to school or higher educational institutes. As a result, children and youth would get trapped in the vicious cycle of poverty of their adults as time passed by.

This community was facing many environmental and health problems simply due to the proximity to the unplanned urban garbage dump. Overcrowding and lack of cleanliness were visible problems. The risk of flooding due to blocked drains is high. In addition, many social and economic problems have arisen due to the garbage dump. Illegal businesses such as drug 
dealing, and prostitution also operate in the community. All these factors have contributed to the community's marginalization from the rest of society.

Public service provision to the community was inadequate to meet their needs, both in quality and quantity. Most community members perceived that the government officers appointed to serve them at the village level were suboptimal in delivering effective services to the community. Further, it was evident that the community members themselves had negative perceptions and attitudes, which further aggravated the complexity of problems they were facing, delaying the development process.

Justification: It is quite evident that this community is facing a large number of problems. Most of these problems are quite complex and need long-term and comprehensive interventions. During the limited period of the community practicum, it was decided to carry out a community-lead needs assessment, which could help the researchers to understand what is perceived as priorities.

Objective: The objective of the case study was to carry out a community-based beads assessment to differentiate between the identified needs and the prioritized needs by the community.

Intervention: Engaging with community members individually as well as groups both formally and informally provided the opportunity to enlist the needs of the community and to compare them against the prioritized needs by the community. The criteria for prioritization were the importance of the problem, time duration available to address the problem by the community, and availability of resources at the disposal of the community to take action against them.

Results: Table 1 summarizes the identified needs against the prioritized needs in the Dahampura community.

\section{Table 1: Identified Vs. Prioritized Community Needs in Dahampura}

\begin{tabular}{|c|c|c|}
\hline Identified needs & No. & Prioritized needs \\
\hline $\begin{array}{l}\text { Proper toilet facilities } \\
\text { (health need) }\end{array}$ & 01 & $\begin{array}{l}\text { Holding the extra } \\
\text { classes for the school } \\
\text { students in the } \\
\text { village with free of } \\
\text { charge (educational } \\
\text { need) }\end{array}$ \\
\hline $\begin{array}{l}\text { Proper drainage } \\
\text { system (health need) }\end{array}$ & 02 & $\begin{array}{l}\text { Increase the } \\
\text { involvement of the } \\
\text { youth in the clubs in } \\
\text { the village (social } \\
\text { need) }\end{array}$ \\
\hline $\begin{array}{lr}\text { Advocating } & \\
\text { community } & \text { members } \\
\text { on r prevention } \\
\text { methods r from } \\
\text { mosquito fever (health } \\
\text { need) }\end{array}$ & 03 & $\begin{array}{lr}\text { Provide } & \text { knowledge } \\
\text { about } & \text { self- } \\
\text { employments for the } \\
\text { community } \\
\text { members (economic } \\
\text { need) }\end{array}$ \\
\hline $\begin{array}{l}\text { Remove the al of } \\
\text { garbage dump (health } \\
\text { need+ social need+ } \\
\text { environmental need) }\end{array}$ & 04 & $\begin{array}{lr}\begin{array}{l}\text { Proper } \\
\text { facilities } \\
\text { need) }\end{array} & \text { toilet } \\
& \end{array}$ \\
\hline $\begin{array}{l}\text { Holding the extra } \\
\text { classes for the school } \\
\text { students in the village } \\
\text { with free of charge } \\
\text { (educational need) }\end{array}$ & 05 & $\begin{array}{l}\text { Proper drainage } \\
\text { system (health need) }\end{array}$ \\
\hline $\begin{array}{l}\text { Increase the } \\
\text { involvement of the } \\
\text { youth for the clubs in } \\
\text { the village (social } \\
\text { need) }\end{array}$ & 06 & $\begin{array}{l}\text { Remove the garbage } \\
\text { dump (health need+ } \\
\text { social need) }\end{array}$ \\
\hline $\begin{array}{l}\text { Provide knowledge } \\
\text { about self- } \\
\text { employments for the } \\
\text { community members } \\
\text { (economic need) }\end{array}$ & 07 & $\begin{array}{l}\text { Advocating } \\
\text { community } \\
\text { members on } \\
\text { prevention methods } \\
\text { from mosquito fever } \\
\text { (health need) }\end{array}$ \\
\hline
\end{tabular}


Through this process, the community identifies its' problems/ needs/strengths by getting together and prioritizes those identified needs according to their importance, time duration, and availability of resources. In addition, the above process develops the confidence and will to work with community members to fulfill those needs.

Some solutions that the community came up with to address the prioritized problems included

- Development of a sanitary drainage system

- Establishing a community space to carry out educational activities for the children

- Support of self-employment, and vocational training activities within the community.

- Awareness-raising on environment conservation

- Construction of sanitary toilets

- Community awareness on financial management including savings

- Establishing religious programs for community members.

Reflections: Working with the community in Dahampura provided insights to the team that social workers needed to reside within the community as much as possible. Such physical proximity to the community can contribute to better engagement with the community to initiate sustained community change processes.

It was found that self-employment activities would not be quite successful in communities like Dahampura since people were happier making money without hard work.

Another powerful lesson was that young people were the easiest and most important group to work with within the community. Further, obtaining community involvement and participation for analyzing and prioritizing their problems was essential in effective program planning. Patience, listening to the people, and respecting their values and customs were necessary for performing well as a social worker in a complexly organized community like Dahampura.
3.3 Community Case Study 3: Women for Community Development and Harmony

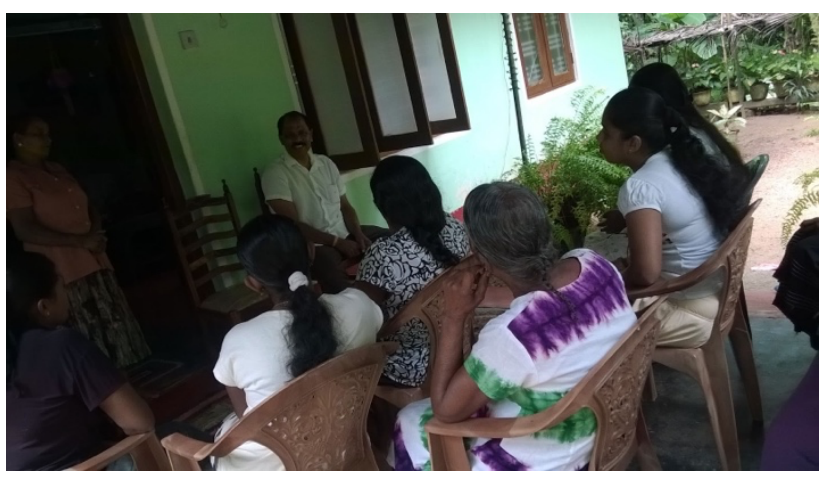

Figure 2: A Meeting with Women in

\section{Danvilana Village}

Background: Danvilana village is located in between the Veyangoda - Airport road in the 328/c GND in the Attanagalla Divisional Secretariat area in Gampaha District. This Grama niladari division was Danvilana. The village spreads on either side of the main road. It is rich in natural vegetation, paddy fields, and other cultivations. However, agriculture is not the primary source of income for the community members since most of them are engaged in government or private sector jobs.

Objective: To engage women in community development and activities.

Justification: The women played a key role in the socio-economic life of Danvilana village. However, the systems to engage women for community development and empower the women through the process were not there. In the meantime, there were no formal mechanisms to promote harmony and cooperation among the women.

Intervention: The social workers facilitated the women of the Danvilana village to develop a list of activities to empower women and build harmony among them. 
Results: The list of activities designed by the women of Danvilana village is as follows:

- Reorganize the Kalanamithuru women cooperative society

- Conduct a health camp regarding women's reproductive health

- Organize a New Year festival to build harmony among the women as well as the rest of the community members.

- Organize the exhibition for their handicraft

- Organize the awareness program regarding their self-employment

- Establish a committee from women's society to provide microcredit facilities for women.

- Identify a location to establish the fiber robe factory and organize a campaign to build it.

- Establish the fiber rope factory in the community to introduce new job opportunities to women who can join any time with their daily routine.

Reflections: This community project was implemented to empower women. Conducting community development projects with participation from women is often a successful approach. When women take the lead, it is easier to get the support of the rest of the community. Women are keen on the economic upliftment of the family and the promotion of health and education of their children. Hence, women's engagement could be effective in interventions targeting education, training, and empowerment projects targeting self-employment, household management, income generation, and saving.

It was found that all women representing the community actively participated in enlisting activities for their empowerment. In addition to identifying the activities, they also identified possible resources which could be tapped to address the problems. It was found that a list of activities developed by women and its process could successfully promote social harmony among women and beyond.

\section{Concluding Remarks}

This paper documented three community cases studies working with three diverse communities from Sri Lanka. The settings where the community work was carried out, the issues that must be addressed, the interventions as well as the lessons learned were quite unique for each community case study. The first case study was directly on promoting harmony in a rural village with an ethnoreligious mix with a history of being near the internal conflict. The group engaged in this setting were children. It was a good idea to get the children engaged in the promotion of harmony since their attitudes and believes still could be positively molded. The ideas generated through working with the children on harmony were quite powerful, with strong recommendations for action at all levels.

The second case study is a clear example of the gamete of complex social, economic, and cultural issues faced by any underserved urban community in Sri Lanka. Given many problems and issues to be addressed, it was probably a wise decision to work with the community itself to prioritize the issues that they wanted to address. It is important to facilitate the community to explore their issues and challenges as well as practical solutions rather than trying to be spoon-feed them with recommendations that often fail in the face of ground realities.

The third case study brought focus on the oftenneglected gender dimension in the development and the social harmony agenda. The women were mobilized to list out the activities that they would like to carry out both for their community development as well as for building harmony within the community.

While the paper highlights the need to work with the community with patience and empathy towards addressing the issues and problems that they face. In the meantime, the three community case studies provide useful learning for future engagement with communities in similar settings. 


\section{References:}

Brager, G., \& Specht, H. (1973). Community Organizing. Columbia University Press.

Bureau of Labor Statistics, U.S. Department of Labor. (2021). Social Workers: Occupational Outlook Handbook: : U.S. Bureau of Labor Statistics. Bureau of Labor Statistics, U.S. Department of Labor. https://www.bls.gov/ooh/community-and-socialservice/social-workers.htm

Canadian Association of Social Workers. (2011, May 6). What is Social Work? Canadian Association of Social Workers. https://www.casw-acts.ca/en/what-socialwork

Chukwu, N. (2019). Methods of Social Work Practice (pp. 47-63).

Department of Social Work. (2017). Introduction to Social Work at Ferris State University. Department of Social Work, Ferris State University. https://ferrisintroductiontosocialwork.pressbooks.co $\mathrm{m} /$

Dredge, D., \& Hales, R. (2012). Community Case Study Research. Handbook of Research Methods in Tourism. https://www.academia.edu/2448674/Community_cas e_study_research

Ife, J. (1995). Community Development: Creating Community Alternatives: Vision, Analysis, and Practice. Longman.

Sri Lanka School of Social Work, National Institute of Social Development, Sri Lanka. (2016). Field Training Manual. Sri Lanka School of Social Work, National Institute of Social Development, Sri Lanka. 